\title{
New editors-in-chief and 40th anniversary of RRR
}

\author{
Mikaela Backman' • Thomas Brenner ${ }^{2}$ Georg Hirte G Iris Wanzenböck $^{4}$
}

Mikaela Backman, Jönköping International Business School (JIBS), and Iris Wanzenböck, Utrecht University, joined Thomas Brenner and Georg Hirte as editors-in-chief of the Review of Regional Research (RRR) in 2020.

Mikaela Backman is an associate professor at JIBS. She has a background in economics and her research focuses on entrepreneurship, regional economics and firm dynamics. Iris Wanzenböck is an assistant professor at Utrecht University. She is educated in economic geography, economics and political science. Her research interests focus on science and innovation, knowledge networks and innovation policy.

These appointments aim at strengthening the RRR that celebrates it's 40th anniversary this year. The German speaking section (GfR) of the European Regional Science Association (ERSA) launched the journal in 1980, named as "Jahrbuch für Regionalwissenschaft". Since 2006 the journal has been published by Springer.

\footnotetext{
M. Backman

mikaela.backman@ju.se

T. Brenner

thomas.brenner@uni-marburg.de

$\bowtie$ G. Hirte

georg.hirte@tu-dresden.de

I. Wanzenböck

i.wanzenbock@uu.nl

1 Jonköping International Business School, Jonköping, Sweden

2 Universität Marburg, Marburg, Germany

3 Technische Universität Dresden, Dresden, Germany

4 University of Utrecht, Utrecht, The Netherlands
} 
In 2013, Klaus Schöler finished his sixteen-year term as editor-in-chief and Georg Hirte jumped in. Shortly afterwards, the journal switched to the current English title "Review of Regional Research" and started to publish almost exclusively papers written in English. Though the journal aimed to focus on regional science, regional economics was the overwhelmingly dominant field in RRR. To change this, Thomas Brenner was invited to become editor and, in 2015, he joined Georg Hirte as editorin-chief. This change actually was very successful in making the journal much more at home in the broad field of regional science. Further, more and more authors from non-German-speaking countries detected the journal and RRR published a couple of special issues focusing on universities and regions.

The new editors are the first non-members of GfR serving as editors-in-chief. They will help strengthening RRR's interdisciplinarity and internationalization. The enlarged team aims at extending the range of topics present in the journal, increasing the network of authors interested in publishing in RRR and expanding the number of published papers per year. The journal is now also present at facebook (reviewofregionalresearch) and twitter (@ReviewRegional).

Funding Open Access funding enabled and organized by Projekt DEAL

Open Access This article is licensed under a Creative Commons Attribution 4.0 International License, which permits use, sharing, adaptation, distribution and reproduction in any medium or format, as long as you give appropriate credit to the original author(s) and the source, provide a link to the Creative Commons licence, and indicate if changes were made. The images or other third party material in this article are included in the article's Creative Commons licence, unless indicated otherwise in a credit line to the material. If material is not included in the article's Creative Commons licence and your intended use is not permitted by statutory regulation or exceeds the permitted use, you will need to obtain permission directly from the copyright holder. To view a copy of this licence, visit http://creativecommons.org/licenses/by/4. $0 \%$. 